\title{
ЛЕКСИКА С ПРОСТРАНСТВЕННЫМ ЗНАЧЕНИЕМ В «НАСТОЯЩИХ СКАЗКАХ» Л. С. ПЕТРУШЕВСКОЙ
}

\section{VOCABULARY WITH SPATIAL SIGNIFICANCE IN "TRUE FAIRY-TALES" OF L.S. PETRUSHEVSKAYA}

\section{E. Plotnikova}

Summary: The article examines the composition and role in the text of the collection "True Fairy-Tales" by L.S. Petrushevskaya vocabulary with spatial meaning. It is noted that the main group of words that convey this semantics are nouns. It was revealed that for the writer the lexemes denoting a local, closed, small space are more important. The conclusion is made about the great importance of vocabulary with the semantics of space for the texts of the collection, representing an ordinary hero in his familiar environment.

Keywords: vocabulary, spatial meaning, noun, "True Fairy-Tales", Lyudmila Petrushevskaya.

\author{
Плотникова Екатерина Андреевна \\ К.филол.н., дочент, ФГБОУ ВО «Марийский \\ государственный университет» \\ kati_miracle@mail.ru
}

Аннотация: В статье рассмотрен состав и роль в тексте сборника «Настоящие сказки» Л.С. Петрушевской лексики с пространственным значением. Отмечается, что главной группой слов, передающих данную семантику, являются имена существительные. Выявлено, что для писательницы более важными оказываются лексемы, обозначающие локальное, замкнутое, небольшое пространство. Делается вывод о большом значении лексики с семантикой пространства для текстов сборника, представляющих обычного героя в привычном для него окружении.

Ключевые слова: лексика, пространственное значение, имя существительное, «Настоящие сказки», Людмила Петрушевская.

Цель статьи - провести анализ лексики с пространственным значением в сборнике Л.С. Петрушевской «Настоящие сказки», выявить её роль в тексте и связь с художественным замыслом автора.

Среди лексики с семантикой пространства в сборнике «Настоящие сказки» наблюдаются имена существительные: даль, остров, берег, город, пристань, балкон и др.; наречия: вверх, вниз, внизу, везде, откуда-то и др.; глаголы: лететь, приплыть, принести и др.; сочетания: другие страны, приличное место, на дне ящика, в деревянном ящичке, вверх по липе и др. Пространственное значение чаще всего передаётся с помощью существительных (в том числе в составе сочетаний), которые в сказках достаточно разнообразны и по семантике (пресс-конференция, гольф-клуб, проулок, тюрьма), и по стилистической окраске (хижина, магазин, библиотека, помойка, рынок).

Можно отметить противопоставление лексем с семантикой масштабного, большого, открытого пространства и слов, обозначающих пространство малое, локальное. Например, в сказке «Волшебница валькирия» героиня «стояла на крыше и смотрела вниз, на человечество, которое копошилось у нее под ногами», при этом мечтая: «власть над миром, над вселенной и т. д.» [7, с. 289]. Количественно преобладают слова и сочетания, обозначающие частное, небольшое, закрытое пространство: квартира, берлога, угол под лестницей, чулан и др. Для Л.С. Петрушевской большое значение имеет точное 
определение места, в котором происходит действие, в котором живут герои сказок. Писательнице совсем несложно перенести своих героев силой фантазии куда угодно, например, «в заоблачные высоты Гималаев, в хрустальный дворец» [Там же, с. 277], но в соответствии с концепцией героя как маленького, обычного человека пространство чаще оказывается маленьким, скромным, но дающим герою ощущение защищённости: «...Внезаnно лимузин развернулся и вместо ночного клуба отвез своего хозяина на квартиру, к одинокому телевизору и трем собакам...» [Там же, с. 59].

Одно из пространств, которые изображает Л.С. Петрушевская в «Настоящих сказках», - потустороннее. О.М. Марал отмечает, что в сказке «Чёрное пальто» автором создано оригинальное изображение «иного мира» [Там же, с. 79]. Героиня рассказа, названная просто «одна девушка», оказывается в неизвестном месте и сначала не может вспомнить, кто она, и понять, где она. Для обозначения пространства автором используется лексика: на краю дороги, в незнакомом месте, на непонятном шоссе [7, с. 103]. Маркерами потустороннего мира становятся лексические единицы лес, дорога, станция и т. п. Геро- иня постепенно начинает вспоминать, что она пыталась покончить с собой, и понимать, что находится в потустороннем мире. Какое-то мгновение она ощущает себя в двух мирах одновременно - «и тут, в темном коридоре перед дымящимся черным пальто, и там, у себя дома, под лампочкой» [Там же, с. 116], а затем возвращается к жизни и оказывается на табуретке, в комнате [Там же, с. 117]. С помощью пространственной лексики автор показывает и смену локаций, и изменение представлений героини о жизни и смерти.

Итак, лексика с семантикой пространства является одной из смыслообразующих координат, создающих категориальную мировоззренческую модель реальности (и нереальности) в сборнике «Настоящие сказки» Л.С. Петрушевской. Данная лексика напрямую связана с теми смыслами, явными и скрытыми, которые транслирует автор своим читателям. Для писательницы очень важно создать локальное, маленькое пространство, в пределах которого существуют её герои и которое осуществляет для них охранную функцию. Наблюдается внезапная смена пространства: от масштабного - к малому, от реального - к потустороннему.

\section{ЛИТЕРАТУРА}

1. Ефименко, Т.В. 0 вторичном переосмыслении метафорической лексики с пространственным значением / Т.В. Ефименко // Вестник Таганрогского государственного педагогического института. - 2013. - № 2. - С. 15-18.

2. Касюк, Н.С. Пространственная и темпоральная лексика в лирике Бориса Пастернака и Андрея Белого / Н.С. Касюк // Вестник Полоцкого государственного университета. Серия А. Гуманитарные науки. - 2008. - № 1. - С. 189-193.

3. Краснокутская, С.Д. Пространственная лексика в цикле повестей Н.В. Гоголя «Миргород» / С.Д. Краснокутская // Гуманитарные научные исследования. 2017. - № 6 (70). - С. 28.

4. Крылова, М.Н. Лексика с семантикой запаха в книгах Д.А. Глуховского из цикла «Метро» / М.Н. Крылова // Русистика без границ. - 2019. - Т. 3. - № 1. C. 29-37.

5. Куркина, Л.В. Система пространственных представлений древних славян (по материалам лексики) / Л.В. Куркина // Славянское языкознание: ХІІІ Междунар. съезд славистов; отв. ред. А.М. Молдован. - М.: Индрик, 2003. - С. 356-375.

6. Марал, 0.М. Изображение потустороннего мира в творчестве Людмилы Петрушевской / 0.М. Марал // Вестник Курганского государственного университета. - 2018. - № 2 (49). - С. 79-83.

7. Петрушевская, Л.С. Настоящие сказки / Л.С. Петрушевская. - М.: Вагриус, 1997. - 399 с.

8. Серебренникова, А.Н. Миромоделирующая функция пространственной лексики в презентационных текстах университета / А.Н. Серебренникова // Вестник науки Сибири. - 2014. - № 4 (14). - С. 196-201.

(с Плотникова Екатерина Андреевна (kati_miracle@mail.ru).

Журнал «Современная наука: актуальные проблемы теории и практики» 